\title{
VOORBEREIDING VIR EN DANKSEGGING NA DIE NAGMAALSVIERING
}

\author{
A.C. BARNARD
}

Die kerk van Jesus Christus het oor die eeue heen aangevoel dat saam met die nagmaalsviering ook ' $n$ voorbereiding daarop en dankbaarheid daaroor moes gaan. Hierdie aanvoeling het egter in die praktyk op verskillende tye van die geskiedenis van die kerk op verskillende maniere en met verskillende aksente gestalte gekry.

Deurgaans is die vraag hoe die nagmaal verstaan is en hoe die werking daarvan gesien is, bepalend vir die voorbereiding daarop en die danksegging daarna. Hier kom die vraag na die nagmaalsleer en die hele teologie van 'n bepaalde kerk na vore.

\section{Die geërfde patroon in Suid-Afrika \\ *'n Geërfde patroon}

Die patroon van die nagmaalsviering, met die voorbereiding daarop en die danksegging daarna, het ons hier net so uit Nederland geërf. So is dit van geslag tot geslag oorgedra. Tot onlangs is nagmaal in die Ned Geref Kerk elke drie maande gevier. Dan is dit 'n groot geleentheid en word dit omraam deur voorbereidings- en dankseggingsdienste.

*Die bekende driesprong

Die voorbereidingsdiens, gewoonlik op die Saterdagmiddag of Saterdagaand. Hier het veral die preek en gebede die aksent laat val op die nagmaal van die volgende oggend, en is getrag om sodoende die gemeente voorbereid by die nagmaal te laat aansit.

Die nagmaalsviering, op die Sondagoggend.

Die dankseggingsdiens, op die Sondagmiddag of Sondagaand waar 'n soort terugskouing gehou is oor die nagmaalsviering wat gehou is.

Hierdie drie dienste is gesien as ' $n$ eenheid en het ook ' $n$ eenheidsboodskap gedra. Gewoonlik is 'n deurlopende tema met subtemas oor die naweek behandel. 
Omdat hierdie oorgeërfde gebruik al so 'n lang pad kom en van geslag tot geslag oorgedra is, en omdat dit sulke diep sentimente raak, daarom voel lidmate dit as ' $n$ heilige verpligting. Baie hou ten alle koste vas aan die bepaalde vorm soos dit bekend is.

\section{*Kerklike navraag}

In die jaarlikse vrae in die Kerkvisitasieverslag en in die verslag van Ampsbediening en Evangelisasie, word gekontroleer deur die Ring of die nagmaal gereeld gevier is en of voorbereidings- en dankseggingsdienste gereeld gehou is. Dus kontroleer die kerk self of hierdie oorgeërfde patroon deur elke gemeente in stand gehou word. Die kerk verwag dus dat alleen só die regte viering van die nagmaal kan geskied.

\section{${ }^{*}$ Die oorgeërfde patroon kom in die gedrang}

Die eerste kraak in die driesprong van voorbereidings-, nagmaals- en dankseggingsdienste het gekom waar die grootste deel van die gemeente nie meer op 'n Saterdagmiddag of -aand na die voorbereidingsdiens gekom het nie. Hulle was net nie daar vir hierdie vorm van voorbereiding nie.

Die tweede skok was dat in baie gemeentes die meeste lidmate ook nie meer in die middag of aand teruggekom het vir die dankseggingsdienste nie.

Hiermee het die geërfde patroon sy trefkrag begin verloor. Oplaas het dit in die gedrang gekom. Omdat dit deur vele as goddelike instellings gesien is, is die verdwyning van hierdie gebruik beklaag en is dit gesien as teken van geestelike verval.

${ }^{*}$ Faktore wat die voorbereidings- en dankseggingsdienste in die gedrang bring

- Saterdagmiddag en -aand word al meer geleentheid vir sport en ontspanning. Hieraan is daar 'n groeiende behoefte by die stadsmens en ons land is vinnig besig om te verstedelik.

- Die gewoonte dat mense al meer net vir die oggenddiens na die kerk kom. Die patroon dat die aanddiens maar ' $n$ verbeeldinglose replika van die oggenddiens geword het en waar nie veel gebied word wat nie reeds die oggend gebied is nie, het die gewoonte versterk. 
- Die sterk kompeterende invloed van die massamedia, veral die televisie, waar baie inte: sssante kyk- en luisterstof gebied word.

- Die besluit van die Algemene Sinode van 1982 waarin ' $n$ beroep op gemeentes gedoen word om 'n meer gereelde nagmaalsviering te hou, verkieslik maandeliks. Hier ondergaan die probleem rondom die voorbereidings- en dankseggingsdienste 'n skaalvergroting.

\section{*Die geërfde patroon onder die soeklig}

In plaas daarvan om die oorgelewerde patroon wat nou uitmekaar val, te beklaag en in plaas daarvan om die mense te verwyt dat hulle dit nie meer nakom nie, moet die kerk homself eerlik afvra of hierdie patroon die enigste is en of daar nie gesonde Bybelse alternatiewe daarvoor is nie.

\section{DIE VOORBEREIDING VIR NAGMAAL EN DIE VRAAG NA VOORBEREIDINGSDIENSTE}

\subsection{Die hou van voorbereidingsdienste in die gedrang}

*Die meeste lidmate kom nie (nie meer nie) na die voorbereidingsdienste nie

Hierdie verskynsel het geleidelik gegroei en oor die land uitgebrei: die gemeente kom nie meer op 'n Saterdagmiddag of -aand byeen vir die vereiste voorbereidingsdiens nie. Hierbo is die belangrikste redes daarvoor aangegee.

\section{${ }^{*}$ Die groot dilemma}

Die hou van voorbereidingsdienste word deur die kerk noodsaaklik geag vir die regte viering van die nagmaal.

Die feitlike probleem is egter dat die gemeente nie daarheen kom nie, maar slegs 'n klein minderheid en dit gewoonlik van die mees toegewyde lidmate. Die groot meerderheid van die gemeente daag wel by die nagmaalsviering op sonder dat hulle by die voorbereidingsdiens was.

Mag hulle onder hierdie omstandighede meedoen aan die nagmaal? Word hulle beskou as minder toegewyd ell moet hulle geloof bevraagteken word? 


\section{*Allerlei uitweë}

'n Voorbereidingsdiens die vorige Sondag. Hierheen kom gewoonlik meer lidmate as na die voorbereidingsdiens op ' $n$ Saterdagaand. Dit is egter nie die hele oplossing nie, want:

'n Deel van hierdie besoekers kom nie na die nagmaal toe nie.

Baie ander was nie hier nie, maar daag wel by die nagmaalsdiens op.

'n Groot deel van die erediens, sowat een derde, bestaan uit dooplidmate wat wel die voorbereiding meemaak, maar nie die nagmaal mag vier nie.

Die groot vraag is of mense ná so 'n voorbereidingsdiens die hele week deur tot by die nagmaal so voorbereid kan bly.

Voorbereiding tydens die biduur of by wyksbidure. Die bedoeling is dat die voorbereiding nader aan die viering moet geskied. Na die biduur kom egter deurgaans slegs ' $n$ baie klein gedeelte van die gemeente, sodat dit nie kan geld as die voorbereiding van die gemeente nie.

Wyksbidure is bedoel vir 'n veel groter bywoning deur die gemeente. Daar is wyke waar die bywoning goed is. Deurgaans is die ondervinding egter dat na elke wyksbiduur ook maar net 'n gedeelte van die lidmate kom. Die gevolg is ook hier dat slegs 'n deel van die gemeente hieraan deel het.

\section{*Die konklusie}

Deur die genoemde uitweë word sommige besware opgevang, maar dit beantwoord nog nie aan die doel met voorbereidingsdienste nie, naamlik dat die gemeente na die nagmaal kom as goed voorbereide mense. Hierdie wyse van voorbereiding word as wesentlik belangrik beskou en die mense word daar verwag - maar hulle kom nie.

\subsection{Enkele skrifgegewens ten opsigte van voorbereiding vir die nagmaal}

\subsubsection{Die Ou Testament}

Die Ou Testament ken die beginsel van voorbereiding waar die mens kom in die ontmoeting met God of waar hy met sy gawe(s) God kom dien.

Voorbereiding van die mens waar hy kom tot die teenwoordigheid 
en ontmoeting met God, byvoorbeeld waar Moses kom by die brandende doringbos ${ }^{11}$, en die volk |srael by die verbondsluiting met God by die berg Sinaï. ${ }^{21}$

Voorbereiding van die regte en beste offers, waarmee die Israeliet voor die aangesig van God kom staan. ${ }^{31}$

Die regte gesindheid by die persoon wat sy offer aan die Here bring - hy bring nie net sy gawes nie, maar hyself word daarby betrokke.4)

Voorbereiding vir die viering van die Pasga. Daar word presies voorgeskryf hoe dit gevier moes word en hoe daarop voorberei moes word.5) Die instelling van die nagmaal vind plaas tydens die Pasga of ten minste in die sfeer van die Pasga.

Die enkelinge en die volk moet heilig wees, aan God afgesonder, in gehoorsaamheid teenoor Hom, in eerbied voor Hom lewe, want God is heilig. ${ }^{6)}$

Hierdie lewe van heiligheid en van gehoorsaamheid, is nie net by sekere geleenthede nie, hoewel dit daar besonderlik aan die lig getree het. Nee, dit is meer ' $n$ lewenshouding, ' $n$ lewe waar die mens begin dink en doen en spreek soos God dink en doen en spreek. Dit alles is die gevolg van 'n blywende verhouding wat aan die basis van die hele lewe lê - die verbond van God met sy volk. Die inhoud van die verbond is dat Hy vir hulle 'n God sal wees en dat hulle vir Hom ' $n$ volk sal wees. ") Soms word dit nog intiemer en dan sê God Hy sal vir die volk 'n Vader wees en hulle sal vir Hom 'n seun wees. ${ }^{8)}$

\subsubsection{Die Nuwe Testament}

*Die verhouding van die mens tot God word verinnig

Die noue gemeenskap tussen God en sy volk, word verdiep in die Nuwe Testament. Daar kom ' $n$ nuwe verhouding tot stand, 'n nuwe gemeenskap, naamlik die kerk. In en deur Christus word God ons Vader en ons sy kinders. As kinders van die Vader is die gelowiges weer ten nouste onderling verbonde as die gesin van God, as die broers en susters van mekaar.9)

\section{Die nuwe lewe in Christus}

Wie tot geloof gekom het, het tegelyk 'n nuwe mens geword wat begin lewe volgens die wil en eise van Christus. Hy vertoon die kenmerke van Christus. Die ou mens met sy sondige neigings word gekruisig. Die gees 
en gesindheid van Christus vul nou die hoof en hart van die gelowige. Dit word 'n lewe vir God en voor God. Daar word 'n nuwe kwaliteit lewe geopenbaar, gekenmerk deur hoop, geloof en liefde. ${ }^{10}$ ) Hierdie nuwe lewe is nie net so nou en dan nie, maar deurgaans. Daarin sit juis inbegrepe 'n groei en toename daarvan. Die gelowiges moet altyd en onder alle omstandighede lewe as die kinders van God. Aan hulle lewe moet die wêreld juis kan sien dat hulle aan Christus behoort. Elke dag is vir die gelowige 'n stryd om in die geloof te volhard.

\section{*Die erediens as samekoms van die gemeente}

Spontaan het die gelowiges saamgekom om die Here in die openbaar te bely en te dien. Omdat die wonder met hulle gebeur het dat hulle aan Christus en aan mekaar verbonde geraak het, daarom was die logiese uitvloeisel daarvan dat hulle in hierdie gemeenskap met Hom en met mekaar wou groei, dit met mekaar wou deel, dit beter wou verstaan en tegelyk wou vier.

Vir hierdie gereelde ontmoeting met Christus en met mekaar in die erediens, het die klem geval op 'n heilige en voorbereide lewe.

\section{*Die nagmaal as besondere konkretisering van hierdie dubbele gemeen- skap}

Die nagmaal is die tafelgemeenskap tussen Christus en sy dissipels en ook weer tussen hulle onderling. Hier word die nuwe gemeenskap met Christus en met mekaar konkreet. Juis in hierdie intieme verhouding moet dit wat hierdie dubbele verhouding belemmer, geweer word en wat verkeerd is, reggestel word. Telkens gaan dit om die dubbele verhouding van die Christus-gemeenskap ${ }^{11}$ en die Christengemeenskap. ${ }^{12)}$ Vanuit sy wese vereis die nagmaal ' $n$ deeglike voorbereiding sodat hierdie dubbele gemeenskap reg verstaan en sinvol beoefen kan word.

*1 Kor. 11:28-32

Ten opsigte van die voorbereiding vir die regte viering en regte verstaan van die nagmaal, kom hierdie uitspraak van Paulus in ' $n$ besondere sin ter sprake. Hy moet die Korintiërs teregwys omdat dit in hulle viering van die nagmaal verkeerd gegaan het. In hierdie gedeelte word veral op twee belangrike sake in die voorbereiding gewys:

- die regte verstaan van die betekenis van hierdie viering, dit mag nie maar onnadenkend geskied nie; 
- die regte voorbereiding daarop deur die verhouding teenoor Christus en teenoor mekaar reg te sien en daaruit te leef. ${ }^{13)}$ Hier het die onderlinge eenheid in die gedrang gekom.

\section{"Voorbereiding 'n werk van God en van die mens}

Soos vir die hele Christelike lewe, so ook die voorbereiding om die nagmaal te vier, geld bo-alles dat dit ' $n$ werk van God is. Omdat God in Christus die hele versoening bewerk het en die mens dit as ' $n$ geskenk ontvang, daarom is voorbereiding in die eerste plek ' $n$ werk van God. Voorop staan die indikatiewe.

As gevolg van die werk van God, moet die mens daaruit lewe, hy moet dit aanvaar, hy moet daarin bly en dit in hom laat werk. Daarom word die mens opgeroep om homself te beproef of voor te berei. As gevolg van die werk van God is voorbereiding ook ' $n$ werk van die mens. Hier kom die imperatiewe tot sy reg.

\section{*Voorbereiding persoonlik en korporatief}

Voorbereiding met die oog op die nagmaal is in die eerste plek ' $n$ korporatiewe aangeleentheid. Dit is die gemeente wat aan tafel met Christus kom. Daarom moet die gemeente as gemeente homself ook voorberei op hierdie groot gebeurtenis. Nooit mag die verbond as basis van die nagmaal vergeet word nie.

Tegelyk staan elke gelowige voor Christus en daarom moet elke gelowige homself ook voorberei om die gebeure van die ontmoeting met Christus en met die ander gelowiges.

\section{*Geree/de nagmaalsviering en gereelde voorbereiding}

Uit die getuienis van die Nuwe Testament kan ons opmaak dat die nagmaal 'n wesentlike deel van die erediens was en dan ook gereeld gevier is. $\mathrm{Na}$ alle waarskynlikheid was dit weekliks gevier. ${ }^{14}$ )

'n Gereelde viering van die nagmaal vereis ' $n$ deurlopende voorbereiding, of liewer 'n hele lewe wat voor God geleef word, 'n voorbereide lewe.

* Wel voorbereiding, maar geen voorbereidingsdienste nie

Uit die gegewens van die Nuwe Testament kan ons met groot sekerheid aflei dat ' $n$ voorbereiding vir die nagmaal nodig geag is en in die praktyk plaasgevind het. Die klem het geval op 'n voorbereide lewe. Daar is egter 
geen gegewens wat wys op 'n boetepraktyk of absolusie of aparte voorbereidingsgebruike of ' $n$ voorbereidingsdiens nie.

\subsection{Historiese flitse ten opsigte van die voorbereiding vir die nagmaal}

\subsubsection{Die Vroeë Kerk}

\section{* Leer en lewe}

Nog steeds word die aksent gelê op sowel die nuwe lewe, die lewe voor God se aangesig, as op die gesonde leer. Hierdie twee hang saam. 'n Geheiligde lewe en 'n gesonde leer is ' $n$ voorbereide lewe en dit is nodig vir die viering van die erediens en in ' $n$ besondere sin van die nagmaal.

${ }^{*} H o \ddot{e}$ eise gestel vir lidmaatskap van die kerk

Wie lidmaat van die kerk wil word, moet dit werklik bedoel en lewe volgens die eise van Christus. Vervolging het hierdie eis versterk. Mense wat tot sekere beroepe behoort het, is weggewys. ' $n$ Hoë sedelike lewe en gesonde leer is as vereistes gestel. Veral in die bloeityd van die kategese van die tweede tot die vierde eeu is besondere aandag gegee aan die voornemende lidmate van die kerk. Lidmaatskap het toegang tot die nagmaal verleen en is gesien as ' $n$ wesentlike deel van die Christen se lewe.

*Gereelde nagmaalsviering en 'n voorbereide lewe

Nog steeds is dit die patroon dat die nagmaal gereeld gevier is en dat 'n deurlopende voorbereiding gegeld het.

${ }^{*}$ Die doop as vereiste

Die primêre eis vir toegang tot die nagmaal was dat so iemand ' $n$ gelowige en weergeborene moet wees - dus 'n gedoopte. Wie nie gedoop is nie, kon nie tot die nagmaal toetree nie. ${ }^{15)}$

\section{*Voorbereiding as deel van die erediens}

In die orde van die erediens en waarin die nagmaal sy regmatige plek gehad het, was daar ' $n$ voorbereiding ingebou. Dit het geskied deur die gebede, veral die Onse Vader, die uitleg van die Skrifte en later deur die 
geloofsbelydenis; ook die feit dat voor die viering van die nagmaal die kategumene en ander nie-lidmate die diens moes verlaat (die missa catechumenorum).

\section{*Vaste}

Tydens die Paasfees is die kategumene gedoop.

Voor die Paasfees was ' $n$ vastyd gehou. Hierdie vaste is gesien as voorbereiding op die fees en op die doop, maar was nie bedoel as voorbereiding op die nagmaal nie. Immers, die gedooptes is direk gelei om aan die nagmaal deel te hê.

\section{${ }^{*}$ Die bieg}

Vroeg reeds het die bieg ' $n$ belangrike plek in die kerk ingeneem. Die vroeë Kerk weet nie van 'n bieg wat in verband met die voorbereiding vir die nagmaal gebring is nie. Slegs een bron, naamlik Didache 14:1 verwys na ' $n$ sondebelydenis as voorbereiding vir die regte nagmaalsviering. Geen ander bron bied iets dergliks nie. In die verwerking van die Didache in die Apostoliese Konstitusies (VII,30), ontbreek hierdie woorde egter.

\section{*Geen voorbereidingsdienste nie}

Die vroeë Kerk ken wel 'n voorbereiding vir die nagmaal, maar ken geen besondere gebruike of ' $n$ spesiale voorbereidingsdiens nie.

\subsubsection{Die middeleeue en die Rooms-Katolieke Kerk}

\section{${ }^{*}$ Die voorbereiding ingebou in die mis}

In die tyd ná Karel die Grote ontstaan op Frankiese gebied liturgies gevormde gebede as voorbereiding tot die nagmaal. Dit kom voor in twee vorms:

Akses of toegangsgebede (Latyn accessus = toegang), waar die priesters hulleself voorberei vir die gang na die altaar. Allerlei apologieë of skuldbelydenisse kom in omloop.

Trapgebede, uit die indrukwekkende intog ontwikkel die gebruik om op die trappe van die altaar persoonlike skuldbelydenisse uit te spreek. Die klerus self bid hierdie gebede.

Uit hierdie skuldbelydenisse ontwikkel die confiteor as die skuldbelydenis van die priester aan die begin van die mis. Dit word ook 'n dialoog van meerdere bidders by die begin van die mis. ${ }^{16}$ ) 
Vir die gemeente kom daar ' $n$ openbare skuldbelydenis met ' $n$ vryspraak in die landstaal by die begin van die maaltyd.

\section{*Die mis ondergaan 'n groot verandering}

Die toenemende realistiese opvatting van die elemente van die nagmaal verkry sy dogmatiese afronding in $1215 \mathrm{nC}$ in die leer van die transsubstansiasie.

Die nagmaal word al meer 'n offer, nie wat Christus vir óns gebring het nie, maar as 'n offer wat die mens aan God bring.

Die mis word al meer gesien as 'n sakramentele skouspel waarin God verskyn (epifanie). Dit lei daartoe dat die lidmate slegs die mis aanskou, maar nie self deelneem nie.

*Die verpligte bieg as voorbereiding

Onder leiding van Pous Innocentius III word op die vierde Lateraanse Konsilie besluit dat:

- dit vir elke lidmaat verpligtend is om ten minste tydens die Paasnag die nagmaal te gebruik;

-'n vastyd van een week voor die nagmaal onderhou moes word;

- die lidmate hulle moes verootmoedig;

- elkeen verplig is om voor die priester te bieg.

Hier kry ons dus vir die eerste keer 'n bepaalde gebruik as voorbereiding vir die viering van die nagmaal.

Provinsiale Sinodes stel voor ' $n$ driemalige gebruik van die nagmaal per jaar en voor elkeen ' $n$ verpligte bieg.

Ten tye van die Reformasie het as algemeen erkende grondreël gegeld dat die bieg aan die ontvang van die nagmaal moes voorafgaan. ${ }^{17}$

\subsubsection{Die reformasie}

Die Reformatore konsentreer nie soseer op die gebede as toerusting tot die nagmaal nie, maar lê eerder klem op die regte verstaan van die nagmaal. Daarom die swaar pedagogiese en kategetiese klem wat in die voorbereiding na vore kom.

\subsubsection{M. Luther}

- Luther beklemtoon die eis van eenheid onder die nagmaalsgangers. Die gemeenskapsgedagte kry 'n swaar gewig. 
- Dit is ook nodig dat die mens sy nood besef. Juis die gevoel van onwaardigheid en kleinmoedigheid moet die mense uitdryf na die troos van die nagmaal.

- Luther beklemtoon die eis van geloof besonder sterk. Vir hom is dit die belangrikste waardige voorbereiding. Hy stel dit dat niemand tot die sakrament moet nader met vertroue op die bieg, gebed of eie voorbereiding nie. Die werk van die Here gaan altyd ons waardigheid en ons bevattingsvermoë te bowe. Die nagmaal kan alleen tot voordeel kom van hom wat glo. Daarom is die wese van die voorbereiding vir die nagmaal die geloof.

Mense moet ondervra word oor hulle geloof.

Later word die ondervraging oor die geloof in die Lutherse ortodoksie tot ' $n$ eksamen oor die opvatting van die nagmaal - 'n Glaubensexamen en dit wel een maal per jaar.

Luther skryf nie die trapgebed of die openbare skuldbelydenis voor vir die voorbereiding nie, maar wel die Onse Vader en die Pax Domini. Hy behou die toerustingsgebed van die priester voor die ontvangs van die kommunie. Die openbare skuldbelydenis word ' $n$ vermaning.

Hoewel hy niemand wil dwing om nagmaal te gebruik nie, spoor hy die mense sterk daartoe aan. Die feit dat Christus ons by die nagmaal wil hê, moet ons daartoe dwing. So ook moet God se beloftes ons na die nagmaal beweeg.

Die voorbereiding op die nagmaal verkry 'n kategetiese en pedagogiese klem. Dit doen hy sterk in 'n preek op Groendonderdag 1523. Luther stel ' $n$ vorm op met vyf vrae en antwoorde wat moet lei tot die regte verstaan van die nagmaal.

\subsubsection{U. Zwingli}

-Zwingli kry ' $n$ brief van Cornelis Hoen uit Nederland waarin hy die realisme by die nagmaal verwerp. In plaas van dat die brood die liggaam van Christus is - hoc est corpus meum - verstaan Hoen dit as aanduiding van Christus se liggaam - hoc significat corpus meum. Hierdie opvatting neem Zwingli van Hoen oor.

- Verder sien hy die nagmaal nie as sakrament of genademiddel nie, maar as ' $n$ moontlikheid vir die mens om sy getuienis te lewer. Bij Zwingli geeft God geen teken meer, maar de mens geeft een getuigenis. ${ }^{18)}$

- In sy Aktion oder Bruch des Nachtmahls sê Zwingli dat die nagmaal 'n 
betuiging is dat ons lidmate van die kerk van Christus is, in die herinnering aan sy oorwinning.

By die nagmaal lê hy die klem op die kerk en nie op die enkeling nie. Die eet van die brood en die drink van die beker is volgens hom uitdrukking van die eenwording met die ander gelowiges, tot een liggaam, die liggaam van Christus. In die nagmaal lê die gelowiges 'n gemeenskaplike wederkerige getuienis af vir mekaar en saam vir Christus. Die liggaam is die kerk van Christus.

Zwingli verwerp die transsubstansiasie van die brood en die wyn in die liggaam en bloed van Christus, maar hy sê daar is 'n transsubstansiasie van die gemeente in die liggaam van Christus. Hierdie liggaam van Christus is die gemeente wat homself aan sy Here as ' $n$ dankoffer bring. Hy skryf: "So bevind die liggaam van Christus hom nie in die brood nie, maar in die gemeente wat rondom die brood versamel is. Daarom moet die mens homself beproef. Want wanneer mens die simbool eet, betuig iy openlik dat jy lidmaat van die kerk is, want wanneer mens van die brood eet en uit die beker drink, word jy een liggaam, naamlik die liggaam van Christus." Hy sê verder dat hierdie deel kry aan die liggaam van Christus die mense verplig tot 'n nuwe Christelike lewe. Wie dit nie doen nie, word deur die ander uitgesluit van die liggaam van Christus.

As voorbereiding behou Zwingli die toerustingsgebede aan die begin van die diens. Verder gebruik hy die algemene of openbare skuldbelydenis en toerustingsgebed met die oog op die kommunie.

\subsubsection{M. Bucer}

- Hy gebruik die Onse Vader, die Confiteor en openbare skuldbelydenis met absolusie, as voorbereiding op die nagmaal.

\subsubsection{J. Calvyn}

Calvyn stel as eerste voorwaarde vir die toegang tot die nagmaal die openbare belydenis van geloof. Daarsonder word niemand toegelaat tot die nagmaal nie. Jaarliks is vier maal 'n ondersoek ingestel waarby die kinders ondervra word oor die kennis en ervaring van die geloof.

Die Sondag voor nagmaal word ' $n$ afkondiging gedoen wat bedoel is om die gemeente aan die nagmaal te herinner en met die oog op die voorbereiding.

Calvyn ag die ondersoek of die beproewing van die self noodsaaklik want wie onnadenkend tot die nagmaal nader of met 'n sondige en onheilige lewe kom, misbruik dit. 
Hoewel Calvyn klem lê op die selfondersoek, waak hy daarteen dat dit sou wees soos by die Roomse Kerk waar die gewetens van die mense daardeur gekwel word.

Die ondersoek met die oog op die nagmaal het veral twee aspekte, te wete:

*'n Ondersoek of ons 'n egte mishae in onsself het. ' $n$ Egte droefheid oor sonde laat ons verlang daarna om ons lewens in te rig volgens die wil van die Here, om ons sondige verlede af te lê en in Hom nuwe skepsels gemaak te word.

*'n Ondersoek of ons 'n ware geloof in Jesus Christus het. Ons moet die vaste vertroue in ons harte hê dat Christus ons enigste geregtigheid, lewe en heil is. Ons moet sy beloftes aangryp en al ons vertroue op Hom alleen plaas. Verder moet ons wandel in die nuwe lewe. Hier is veral die onderlinge liefde van die grootste belang.

Die nagmaal is om ons swakheid te hulp te kom en ons geloof te versterk - daarom moet ons kom in hierdie verwagting.

Die eintlike voorbereiding vir die toegang tot die nagmaal is ingebou in die nagmaalsdiens self:

* In die prediking geskied die bediening van die sleutelmag en wat skeiding tussen mense maak.

* Die formulier was bedoel om die betekenis van die nagmaal en daarom die regte viering daarvan aan te gee. Dit het 'n pedagogiese en kategetiese karakter gedra.

* Die openbare belydenis van skuld en die vryspraak wat daarop gevolg het. Hy grond die vryspraak op die belofte van vergewing van sonde in die evangelie.

* Na die preek volg 'n toerustingsgebed vir die lidmate sodat hulle die nagmaal gelowig kan ontvang.

*Hierop volg die Onse Vader, die Apostoliese Geloofsbelydenis en die instellingswoorde - alles nog as voorbereiding op die nagmaal.

Die tug funksioneer rondom die nagmaal. Hier lê die eintlike taak van die ouderlinge. Jaarliks word ' $n$ ondersoek by elke gesin ingestel deur die ouderling en die predikant. By hierdie ondersoek word gelet op die erediensbywoning, op die leer en lewe van elkeen, maar bowe-al op die geloof.

Calvyn het gepleit vir 'n gereelde nagmaal, weekliks indien moontlik. Dit het ook sy siening van die voorbereiding beïnvloed. 


\subsubsection{Die v/ugtelinggemeente te Londen}

Hier vind ons ' $n$ merkwaardige ontwikkeling, want hier vind ons vir die eerste keer bepaalde voorbereidingsdienste met die oog op die nagmaal. Ons bemerk ten opsigte van hierdie saak die invloed van Zwingli. Die voorbereiding wat hy laat sentreer het om die toewyding aan God en die deelhebbing aan die gemeente as die liggaam van Christus, kry hier 'n sterker ontwikkeling.

J. à Lascio. Hy bepaal in sy kerkorde, Forma ac Ratio (1551) die volgende:

'n Kennisgewing/aankondiging die vorige Sondag dat die nagmaal gehou sou word. Die nagmaal is maandeliks gevier. ' $n$ Voorbereidingsdiens is gehou die Saterdag voorafgaande aan die viering.

By hierdie voorbereidingsdiens is 'n swaar aksent gelê op die selfondersoek met die oog op die nagmaalsviering.

Wie nagmaal wou gebruik, moes hom aanmeld by die ouderling.

M. Micron. In sy kerkorde, De Christelicke ordinancien ... (1554) bepaal hy die volgende ten opsigte van die voorbereiding vir die nagmaal:

Veertien dae voor die nagmaalsviering geskied 'n oproep tot die gemeente tot selfondersoek. Die nagmaal is tweemaandeliks gevier.

'n Voorbereidingsdiens is gehou die Saterdag voor die nagmaal.

By hierdie voorbereidingsdiens word groot erns gemaak met die selfondersoek. ling.

Wie nagmaal wou gebruik, moes hom aanmeld by die ouder-

By die nagmaalsdiens van Micron, net soos by dié van à Lasco, was ook verskillende elemente ter voorbereiding op die ontvang van die nagmaal.

\subsubsection{Die Kerkorde van die Pa/ts, 1563}

By hierdie kerkorde, wat sterk op Calvyn teruggaan, vind ons ook die eienaardige gebruik van 'n voorbereidingsdiens op die Saterdag voor die nagmaal. Sou dit die invloed van Londen wees?

Agt dae voor die nagmaal geskied 'n bekendmaking met die oog op die voorbereiding van die jongmense vir toetrede tot die nagmaal.

Saterdag voor die nagmaal word ' $n$ voorbereidingsdiens gehou.

In die prediking hier gaan dit veral om die voorbereiding vir en die 
selfondersoek van die mense, met die oog op die viering van die nagmaal.

Aan die slot van die preek was 'n vyftal vrae wat gedien het as ondervraging van die jongmense wat vir die eerste keer aan die nagmaal wou deelneem.

$\mathrm{Na}$ die toelating van die jongmense is drie vrae aan die hele gemeente gestel wat gehandel het oor:

* die kennis van sonde;

* die geloof in die verlossing van Jesus Christus;

* die voorneme om van nou af 'n dankbare en gehoorsame lewe volgens God se gebooie te voer.

Die Sondag met die viering van die nagmaal was daar die ondersoek deur die formulier en was daar verder dieselfde toerustingsdeel as dié van Straatsburg.

\subsubsection{Die voorbereiding op die nagmaal in Nederland}

In Nederland word die gebruik van die vlugtelinggemeente te Londen oorgeneem. Nagmaal is ook twee-maandeliks gehou.

Op die Saterdag voor die nagmaal is ' $n$ voorbereidingsdiens gehou.

By die voorbereidingsdiens moes 'n eenvoudige preek gehou word, waarin gehandel moes word oor die selfondersoek van die gemeente en die versoenende genade van God (Sinode van Dordt, 1574). By die Sinode van Dordt 1618, word die nut van die hou van 'n voorbereidingspreek genoem, maar nie voorgeskryf hoe dit gehou moes word nie.

Die praktyk van Calvyn van huisbesoek deur die ouderlinge voor nagmaal, is nagevolg.

Die formulier vir die nagmaal is met die nagmaalsdiens gelees en daar was in hierdie diens verdere handelinge ter voorbereiding op die nagmaalsviering.

\subsubsection{Voorbereiding op die nagmaal by die Nadere Reformasie}

By hierdie beweging van die Nadere Reformasie in Nederland kom daar ' $n$ belangrike verandering van die klem in die voorbereiding op die nagmaalsviering. Hier word gelet op manne soos $G$ Voetius, W à Brakel, J Verschuir, Jodocus van Lodenstein, $W$ Teellinck, $P$ Immens, en andere.

Daar vind ' $n$ voortgaande verskuiwing van aandag rondom die nagmaalsviering plaas. Die klem val steeds minder op Christus en op die verlossing wat Hy bewerk het, en steeds meer op die Christen en op sy 
geestelike toestand. Hý moet waardig wees om die nagmaal te kan vier.

Die aandag word verlê van die viering van die nagmaal na die voorbereiding daarop en dan veral op die grondige selfbeproewing.

Die selfondersoek verkry 'n swaar subjektiewe aksent. Dit word subjektiewe meditasie saam met 'n perfeksionistiese vroomheid.

Die vrome en waardige mens word nou baie belangrik. Die lig val op die mense wat nie so waardig is nie, op die "onbekeerdes" of "skynbekeerdes". Hulle moes van die nagmaal weggehou word.

Veral by Willem Teellinck en Jodocus van Lodenstein word klem gelê op die mens se verpligtings en op sy inspanning. Daar is te min aandag vir die werk van die Heilige Gees.

Die nagmaal as objektiewe genademiddel, waardeur Christus sy genade skenk en die geloof versterk, verloor al meer sy plek. Die mens bewys sy getrouheid en lojaliteit teenoor die Here. Hier vind ons raakvlakke met Zwingli se standpunt.

\subsubsection{Voorbereiding op nagmaal in Suid-Afrika}

In Suid-Afrika is die Nederlandse patroon net so oorgedra, dit wil sê die voorbereidingsdiens op die Saterdag voor die nagmaal, terwyl hier in die preek die klem op die voorbereiding op die nagmaal geval het.

Afgesien van die voorbereidingsdiens, is op die Sondag by die nagmaalsdiens, voorbereiding gehou deur die formulier en deur die ander toerustingshandelinge.

Hier het dit gebruiklik geword om elke drie maande die nagmaal te vier en was daar dus lang tussenposes tussen die vierings, wat weer die eis om 'n deeglike voorbereiding versterk het.

Ook die invloed van die Nadere Reformasie is hier deeglik gevoel.

As gevolg van die groot afstande en die gebrekkige vervoermiddele het 'n praktyk hier ontwikkel van 'n nagmaalsnaweek, waar mense vir die driemaandelikse nagmaalsviering na die dorp of kerkplek kom. Dan is kinders gekatkiseer, mense gedoop, vergaderings gehou en so kon die driesprong van die nagmaal, te wete die voorbereidingsdiens, die nagmaalsdiens en die danksegging, gehou word.

\subsection{Wyse van voorbereiding op die nagmaalsviering}

\section{*Die beeld uit Skrif en geskiedenis}

Uit die gegewens van die Skrif en volgens die opvatting van die kerk deur die geskiedenis, moet gekonkludeer word dat 'n deeglike voorbereiding op die viering van die nagmaal noodsaaklik is. 
Hoewel op verskillende maniere het hierdie voorbereiding deur die geskiedenis steeds plaasgevind.

Ook tans moet die eis van 'n deeglike voorbereiding vir toetrede tot die nagmaalsviering onverkort gestel word. Elkeen wat die nagmaal wil vier en die gemeente as geheel, moet na deeglike voorbereiding na die nagmaal kom.

\section{*'n Deurtopende voorbereiding}

Die gesonde, Bybelse siening van voorbereiding is dat dit nie slegs vir ' $n$ geleentheid moet wees nie, maar elke dag moet gebeur.

Die egte voorbereiding behels:

'n geheiligde lewenswandel, waar geleef word in gehoorsaamheid teenoor die Here, waar Hy gedien en geëer word;

'n gesonde leer, waar aan die hele Bybelse boodskap onverkort vasgehou word.

Op hierdie deurlopende en voortdurende voorbereiding op die nagmaal, moet veel meer aksent gelê word.

*Voorbereiding by die nagmaalsdiens self

Vanaf die begin van die Christelike kerk, was die eintlike voorbereiding op die viering van die nagmaal ingebou in die diens self. Eers was dit baie eenvoudig, later is dit meer liturgies uitgebou, maar steeds het dit plaasgevind.

Ook tans behoort dit veel sterker besef en beleef te word dat die noodsaaklike voorbereiding in die nagmaalsdiens self geskied. Daarvoor is ruim voorsiening gemaak in die formulier, in die openbare skuldbelydenis en genadeverkondiging, in die toerustingsgebed, in die geloofsbelydenis voor die viering, in die liedere.

\section{*Voorbereidingsdienste}

Eers baie laat in die geskiedenis van die kerk ontstaan daar besondere en verpligte voorbereidingsgebruike, soos die vas en bieg. Eers veel later en dit aan die rand van die groot stroom van die Christelike Kerk, het spesiale voorbereidingsdienste ontstaan.

Ongetwyfeld het dit ' $n$ betekenis gehad in ' $n$ bepaalde omstandigheid, en het dit 'n belangrike doel gedien. Absoluut noodsaaklik was dit geensins nie.

Waar die spesiale voorbereidingsdienste tans in die gedrang gekom het, kan die saak van deeglike voorbereiding op die nagmaal voortgaan, 
sonder sulke spesiale dienste. Hier moet dit duidelik gestel word dat sulke voorbereidingsdienste nuttig was, maar nie noodsaaklik is vir die regte viering van die nagmaal nie.

\section{*Groter sorg aan die besoek en tug rondom die nagmaal}

Vir die regte viering van die nagmaal en die regte voorbereiding daarop behoort veel sterker klem gelê te word op die huisbesoek aan lidmate voor die nagmaal deur die ouderlinge. Hier behoort die opsig en toesig veel sterker na vore te kom.

Hiermee hang onvermydelik saam die vraag na die deeglike en konsekwente toepassing van die kerklike tug en dit in die regte gesindheid. Die intieme gemeenskap tussen die gemeente en Christus by die nagmaal en die intieme onderlinge gemeenskap, vereis die gesonde funksionering van die kerklike tug.

\section{*Voorbereiding aan die tuisfront}

Die openbare godsdiensbeoefening stoel op die private beoefening daarvan. Dit geld veral ook die voorbereiding vir die nagmaal. In aanvulling by die voorbereiding in die erediens, behoort veel meer gemaak te word van die voorbereiding in die persoonlike stiltetyd en die persoonlike dien van die Here. Hierby kom die gereelde en sinvolle waarneming van die huisgodsdiens, waar die hele gesin die Here dien.

Hierby kan groepsbyeenkomste, wyksbyeenkomste of ander byeenkomste aanvullend gebruik word.

\section{${ }^{*}$ Gereelder nagmaalsviering}

'n Meer gereelde viering van die nagmaal bring ook mee dat op 'n meer deurlopende wyse aan die voorbereiding aandag gegee word.

\subsection{Waaroor dit by die voorbereiding gaan}

\section{*Erkenning van God}

By elke nadering tot God en by elke ontmoeting met Hom, moet ons altyd opnuut weer deurdronge wees van sy grootheid, sy heiligheid, sy majesteit - maar tegelyk ook van sy liefde, sy genade en sy toegeneentheid teenoor ons. 
*Erkenning van die betekenis van en bedoeling met die nagmaal

Wat die nagmaal vir ons beteken en hoe ons die werking daarvan sien, sal ook die voorbereiding daarop bepaal. Paulus se oproep tot selfondersoek gaan juis uit van die regte verstaan van die betekenis van en die bedoeling met die nagmaal.

Erkenning van die betekenis van die nagmaal moet verhinder dat ons dit agteloos en onnadenkend gebruik.

Erkenning beteken dat alles wat ingaan teen die dubbele bedoeling met die nagmaal, naamlik:

Die intieme gemeenskap van die gemeente en die gelowiges met Christus, en

Die allernouste onderlinge eenheid en eensgesindheid van die gelowiges,

geweer moet word, maar juis alles wat dit bevorder, nagejaag moet word.

\section{*Selfkennis en sondekennis}

Erkenning van die heilige God en die diepe betekenis van die ontmoeting met Hom en met mekaar, bring die gemeente en die gelowiges daartoe om die eie self te ken. Voorbereiding vir die nagmaal beteken daarom ook die erkenning van die eie sonde en skuld van versuim en bedryf, die eie sondigheid en verlorenheid. Egte selfkennis beteken ook altyd sondekennis en berou oor sonde.

\section{${ }^{*}$ Die herstel}

Selfkennis en sondekennis moet die gelowige altyd uitdryf tot Christus, waar die sonde bely kan word, waar sy vergifnis verkry kan word, waar die groot herstel tussen God en die mens en ook tussen mens en mens, verkry kan word. Die nagmaal roep om die versoende mens - versoen met God en met sy medemens, en dikwels ook versoen met jouself. Versoening beteken altyd positief om God se heerlike beloftes aan te gryp en daaruit te leef.

\section{*Van nou af anders}

Herstel van die dubbele verhouding tot God en tot die medemens beteken verder dat mens in 'n nuwe lewe te staan kom, al is dit vir die soveelste keer. ' $n$ Voorbereiding wat eg is, beteken ' $n$ voorbereide lewe, dit is 'n egte Christelike lewe, waar God erken, bemin, gedien, van Hom getuig en $\mathrm{Hy}$ geloof word. 


\section{*Persoonlik en korporatief}

Egte voorbereiding vir die nagmaal raak elke enkele gelowige. Ewe-eens raak dit al die gelowiges saam, die hele gemeente - 'n korporatiewe voorbereiding. Immers daar is gemeenskaplike sondes, groepsondes, kerksondes, volksondes.

\section{DANKBAARHEID EN DANKSEGGINGSDIENSTE NA DIE NAGMAALSVIERING}

\subsection{Die patroon van dankseggingsdienste in die gedrang}

\section{*Die ou patroon}

Die ou patroon vir die viering van nagmaal het voorsiening gemaak vir ' $n$ aparte diens na die nagmaal te wete as ' $n$ dankseggingsdiens.

Veral onder die invloed van die Nadere Reformasie is daarvan gepraat as 'n nabetragtingsdiens.

\section{*Die driesprong het verval}

Soos hierbo aangetoon is, het die ou driesprong van die voorbereidingsdiens, 'n nagmaalsdiens (of aksiediens) en 'n dankseggingsdiens, uitmekaar geval. Dit het gebeur as gevolg van allerlei oorsake en omstandighede.

Die kerk verwag nog die lidmate by die dankseggingsdiens, maar hulle bly nie vir, of kom nie weer na, die dankseggingsdiens die aand nie.

\section{*Nuwe weë word gevolg}

Soos by die voorbereidingsdienste, word ook hier ander weë gevolg om tóg 'n dankseggingsdiens te hou:

Die dankseggingsdiens word verskuif na die volgende Sondagoggend. Die probleem is dat by hierdie geleentheid talle mense is wat nie by die nagmaal was nie en ander wat wel daar was, nou nie hier is nie. Sowat 'n derde van die aanwesiges is dooplidmate wat gewoonlik by die nagmaal nie teenwoordig was nie.

Die dankseggingsdiens word 'n kort rukkie na die nagmaalsdiens gehou:

* Soms 'n uur na die nagmaalsdiens

*Soms net 'n halfuur na die nagmaalsdiens. 
Hier word kort na 'n vol en ryk nagmaalsdiens, waar elke element ' $n$ besondere betekenis het, weer ' $n$ ander diens gehou. Dit kan alleen beteken dat so die betekenis van die nagmaalsdiens gedevalueer word. So dra dit ook by dat mense 'n onbehae en frustrasie beleef teenoor die nagmaal.

Die dankseggingsdiens word in direkte aansluiting by die nagmaalsdiens gehou. Daar word net 'n lied opgegee en dan volg die dankseggingsdiens sonder meer. Hier geskied 'n ernstige misbruik, sowel wat die nagmaal betref as teenoor die nagmaalgangers. So word mense ooreis met ' $n$ oorvloed wat nie sin maak nie, maar juis daardeur word hulle geweldig verarm omdat niks só tuiskom nie.

Hierdie nuwe weë beteken in werklikheid dat iets gedoen word, nie omdat dit noodsaaklik is nie, maar om 'n bepaalde gebruik in stand te hou. Dit is formalisme in die ergste graad.

\subsection{Die lig van die Nuwe Testament}

\section{*Die eis van dankbaarheid}

Soos 'n goue draad loop die gedagte van dankbaarheid deur die Nuwe Testament, as die eerste en beste reaksie by die mens op die groot wonder van die verlossing deur Jesus Christus. Ons kan sê dit is dié kenmerk van die verloste mens. Hierdie dankbaarheid is ook weer nie 'n prestasie van die mens nie, maar is die reaksie op die ontmoeting met God, op sy aanraking, op sy werk aan die mens.

\section{${ }^{*}$ Dankbaarheid deur die hele lewe}

Dankbaarheid kom as die blywende reaksie op die werk van God in die mens. Hierdie reaksie word steeds verlewendig en stroomversnellings geskied by elke nuwe openbaring van God, by elke nuwe ontmoeting, by elke nuwe aanspreking deur Hom.

Daarby geskied die dankbaarheid deur woord en daad.

Dit geskied voor God se aangesig, in die privaat, maar ook in die openbaar saam met die gemeente.

Die dankbaarheid kom tot openbaring op elke terrein van die lewe, onder alle omstandighede en té alle tye.

\section{${ }^{*}$ Geen spesiale dankseggingsdienste nie}

Die Nuwe Testament ken nie aparte dankseggingsdienste nie. Elke erediens was 'n stuk danksegging en gewoonlik is tydens elke diens die nagmaal gevier. 


\subsection{Dankbaarheid ná die nagmaal deur die kerk geïnterpreteer}

\section{*Dankseggingsdienste onbekend}

Die Vroeë Kerk, die kerk deur die middeleeue, die Rooms-Katolieke Kerk, die Kerke van die Reformasie ken nie 'n aparte dankseggingsdiens nie.

Vir die ontstaan daarvan moet ons ook weer gaan na die vlugtelinggemeente te Londen.

In Nederland het die Sinode van Dordrecht, 1574, dit liturgies verstaan as 'n náviering, as post-communio, van die nagmaal, waarin die gelowiges gewys is op Christus se groot liefde teenoor hulle en dat hulle ook teenoor Hom wederliefde verskuldig is. Verskillende sinodes het bepaal dat gedurende die namiddagdiens uit die kategismus gepreek moes word. Die Sinode van Middelburg, 1581, het die vryheid gelaat om naas die kategismus ' $n$ aparte dankseggingsprediking te hou.

\section{${ }^{*}$ Die danksegging ingebou in die nagmaalsdiens}

Vanaf die begin van die liturgiese vormgewing van die nagmaalsdiens, vind ons die sterk aksent op die lof en danksegging aan God ingebou in die diens. So vind ons dit vanaf die eerste geskrifte oor die erediens buite die Nuwe Testament, in die brief van Plinius aan keiser Trajanus (c. $112 \mathrm{nC}$ ), in die eerste volledige liturgie bekend, dié Apologie van Justinus die Martelaar, $(150 \mathrm{nC})$, en dwarsdeur verder.

Baie vroeg reeds was daar die sterk ontwikkelde "eucharistiegebed", waarin die lof en dank aan God sterk op die voorgrond gestaan het. Hierdie gedagte het so sterk geheers dat die hele diens dikwels as eucharistie aangedui is.

Dwarsdeur die verskillende liturgieë, ook dié van die Gereformeerde Protestantisme, kom die sterk klem op die lof en danksegging duidelik na vore.

\section{*Die danksegging by elke diens}

Dit is opvallend, maar vanselfsprekend dat die danksegging nie net gereserveer is vir die nagmaalsdiens nie, maar dat dit die kenmerk van elke erediens was. Natuurlik is die nagmaal meer dikwels gevier. Dit sou 'n geweldige leemte gewees het indien die danksegging net gereserveer sou wees vir die enkele nagmaalsdiens, terwyl by die ander dienste dit nagelaat sou wees. 
Die kerk het steeds, al is dit op verskillende maniere, die Nuwe-Testamentiese eis van 'n lewe van dankbaarheid, voorop gestel. Hulle het steeds verstaan dat dankbaarheid nie slegs gesê of uitgespreek moet word nie, maar uitgeleef moet word in die konkrete lewe.

\subsection{Dankbaarheid en dankseggingsdienste ná die nagmaalsviering}

\section{*Dankbaarheid is noodsaaklik}

Met die grootste klem moet die Bybelse eis van dankbaarheid teenoor God vir sy groot werk aan ons en wat steeds by die nagmaal versterk en gekonkretiseer word, gehandhaaf word. Dankbaarheid bly steeds dié een groot kenmerk van die lewe van die Christen. Alles wat hy is en doen, word daardeur bepaal.

\section{*Dankbaarheid in elke diens}

Soos steeds in die private omgang met God, en by die huisgodsdiens, so moet ook die dankbaarheid teenoor God by elke erediens in die openbaar tot uitdrukking kom. Ons kan tog nooit byeenkom en van sy wonderlike liefde en genade geniet en nooit met diepe dankbaarheid daarop antwoord nie.

\section{${ }^{*}$ Dankbaarheid ingebou in die nagmaalsdiens}

Deur die geskiedenis is dit steeds in die verskillende liturgiese vorms gedoen en so geskied dit ook in die inrigting van die nagmaalsdiens in die Ned. Geref. Kerk. Daar is 'n duidelike tendens van dank en lof aan God. Duidelik word beklemtoon dat wie Christus werklik ontmoet het saam met die broeders en susters, nou saam met hulle Hom loof en dank. Dit begin reeds hier by die nagmaalsdiens maar loop daarvandaan dwarsdeur die hele lewe.

\section{*Dankbaarheid deur die hele lewe}

Dankbaarheid teenoor die Here vir sy groot gawes, is wat mens in jou hart oor en oor sê.

Jy sê dit egter ook saam met ander en voor ander mense. Dit geskied in die kerk waar ons sing en bid en bely en die offergawes gee. 
Jy bly dit egter oral sê waar jy in die lewe kom.

Dankbaarheid word egter nie slegs gesê nie, maar gedoen, uitgeleef; dit geskied ook met die daad. Die sterkste daaddankbaarheid is deur die nuwe lewe in Christus konsekwent uit te leef.

\section{*Dankbaarheid sonder dankseggingsdienste}

Spesiale "dankseggingsdienste" na die nagmaal is nie nodig nie. Al wil dit die dankbaarheid verhoog, bring dit juis die hele saak van dankbaarheid in die gedrang. Wat ons bo-alles nodig het is dat die gemeente en elke gelowige elke dag lewe en werk as dankbare mense, maar nie 'n dankseggingsdiens na elke nagmaalsviering nie.

\section{${ }^{*}$ Die probleem met dankseggingsdienste}

Die eerste vraag wat opkom is wat met so 'n diens bedoel word. Waarvoor word hier gedank? Is dit vir die heerlike verlossing in Jesus Christus? Maar dan behoort ons ook op so ' $n$ wyse Hom te dank na elke ander diens. Is dit die ekstra versekering en seën wat in die nagmaal ontvang word? Indien wel, dan word die genade van die sakrament gestel bo dié van die Woord en Gees. Daarby word die nagmaal geïsoleer ten opsigte van die ander eredienste. Word die seën by die dankmaal gestel as dié rede tot danksegging, kom die verdere vraag wat nou van die ander sakrament, naamlik die doop? So word 'n groot onderskeid gemaak tussen die ontvang van die doop en die nagmaal. Wat erger is, is dat die doop maar eenmaal in die lewe ontvang word, terwyl die nagmaal telkens gevier word.

So ' $n$ aparte dankseggingsdiens en wat juis die dankbaarheid wil bevorder, werk dit juis teen. Waar ná die nagmaal die gemeente spesiaal byeenkom om te kom dank, het dit die konsekwensie dat die nagmaal nou afgesluit word en dus afgehandel is en dat ons nou weer verder kan voortleef. So werk dit mee dat die lidmate se dankbaarheid afgesluit word en werkeloos word en dat dit nie die grondtoon deur die lewe bly nie.

Waar by die dankseggingsdiens ook nog die verdere ondertone van subjektiewe meditasie, van koestering van die eie vroomheid en van ' $n$ nabetragting verstaan as die sirkulasie van ' $n$ mistieke vroomheid, meeklink, maak dit die diens verder problematies.

\subsection{Die aard en inhoud van die dankbaarheid}

Die dankbaarheid wat die hele lewe van die Christen en van die ge- 
meente moet kenmerk, en wat telkens weer by elke nagmaalsviering verinnig en verlewendig en verdiep moet word, het veral die volgende groot kenmerke:

\section{*Dankbaarheid as gevolg van die herstelde verhouding}

Die diepste oorsaak van, die oorsprong en bron van alle dankbaarheid is die liefde en genade en verlossing wat die mens van God-drie-enig ontvang, sodat hy bevry word van al sy sonde en skuld en in die herstelde verhouding tot God en tot die medemens kan lewe. Al die ander seëninge en gawes wat ontvang word, vloei uit hierdie basiese gebeure en bou dit net verder uit. Alle egte dankbaarheid moet uit hierdie wortel groei. Dankbaarheid vir ander kleiner gawes mag nie geïsoleer word van die basiese versoening met God en wat steeds vernuut moet word nie.

\section{*Dankbaarheid as 'n lewe van toewyding}

Dankbaarheid is nooit net ' $n$ opwelling van emosie nie. Dit beteken dat wie met die Here versoen is, in hierdie versoening wil bly; dat wie Hom ontmoet het, naby Hom wil bly; dat wie sy liefde gesmaak het, hierdie liefde steeds wil beantwoord; dat wie sy eiendom geword het, homself onvoorwaardelik tot sy beskikking stel.

\section{*Dankbaarheid as 'n lewe van diens}

Wie aan die Here behoort en by Hom bly, staan ook in sy diens en tot sy beskikking. Hierdie dienslewering is binne die kerk maar ook daarbuite, dit omvat die geestelike en tydelike node van die mens, dit word gedoen as 'n groot voorreg en nie as 'n swaar plig nie.

\section{*Dankbaarheid as 'n lewe van getuienis}

Getuienis hang ten nouste saam met diens, maar gaan ook verder. In die getuienis word gewys op Jesus Christus, op sy verlossing in elke konkrete situasie en vir die egtheid daarvan word met die eie lewe ingestaan. Getuienis geskied in die krag van die Gees.

\section{*Dankbaarheid as 'n lewe van kontinuiteit}

Dankbaarheid vir al die gawes van die Here het wel 'n begin, maar nooit ' $n$ einde nie. Dit is nie net vir ' $n$ geleentheid en dan is dit weer klaar nie. Nee, dit geskied telkens en telkens weer. Elke keer kom daar nuwe im- 
pulse wat die dankbaarheid opnuut wakkerroep. Die dankbaarheid loop van

- dag tot dag

- week tot week

- nagmaal tot nagmaal

- die dag van die bekering tot aan die einde van die lewe of tot by die wederkoms van Christus.

\section{*Dankbaarheid as 'n lewe van vreugde}

Dankbaarheid word wakkergeroep deur die werk van God in ' $n$ mens se lewe. Jy word daardeur ' $n$ nuwe mens wat leef uit ' $n$ ander beginsel, losgemaak van 'n verkeerde verlede, bevry vir 'n nuwe hede en verwag ' $n$ heerlike toekoms. Dit alles lei tot die diepe dankbaarheid wat tegelyk ' $n$ vreugde is wat nie hoef te verwelk nie. Hierdie vreugde stempel die hele lewe, hoewel dit altyd weer nuwe hoogtepunte bereik.

*Die kroon van alle dankbaarheid

Die spits, die kroon, die eindbestemming, die voile verwesenliking van alle dankbaarheid is die lof, eer, verheerliking en aanbidding van Goddrie-enig. Hiermee word egter nie aan God iets gegee wat Hy nie gehad het nie, maar word iets van wat Hy eerste aan ons gegee het, aan Hom teruggegee.

\section{Notas}

1) Eks 3:5,6.

2) Eks 19:10vv.

3) Eks $12 ; 34: 20,23 ; 23: 17$.

4) Lev 3-7; Eks 23:19; 34:26; Jer 6:2; 7:3vv; 14:12.

5) Eks 23:14vv; Lev 23; Deut 16.

6) Eks 19:6; 22:31; 29:45; Lev 11:44,45; 19:2; 20:6; 26:12; Deut 7:6; 14:2,21; 26:19.

7) Eks 6:6; 29:45; Jer 24:7; 31:33.

8) 2 Sam 7:14; Eks 4:22,23; Op 21:7.

9) Vgl D. Guthrie, New Testament Theology 1981, 701vv; G.E. Ladd, A Theology of the New Testament 1975, $342 \mathrm{ev}, 479 \mathrm{ev}$.

10) Vgl J.H. Roberts, Die kerk by Paulus, in: Handleiding by die Nuwe Testament V 1984 $282 \mathrm{ev;}$ L. Goppelt, Theologies des Neuen Testaments (Hrsg J. Roloff), I. Teil 1975, $128 \mathrm{ev} ; \mathrm{J}$. Jeremias, Neutestamentliche Theologie. I. Teil 1973, $157 \mathrm{ev.}$

11) 1 Kor 10:16.

12) 1 Kor 10:17, vgl W.G. Kümmel, Die Theologie des Neuen Testaments 1972, $196 \mathrm{ev}$ 225. 
13) Vgl J.F. Pop, De eerste brief van Paulus aan de Corinthiërs 1965; W.G. Kümmel, Einleitung in das Neue Testament 1980, 42, 422; Guthrie, a.w., $719 \mathrm{ev} ; 729 \mathrm{ev}, 757 \mathrm{ev}$.

14) Vgl A.C. Barnard, Die Erediens ${ }^{2} 1985,138$ et passim.

15) Did 9; Justinus Apol 1, 65, 66.

16) Vgl verder B. Klaús, Die Rüstgebete, in Leiturgia, II 1955, $523 \mathrm{ev.}$

17) Vgl verder G. Rietschel, P. Graff, Lehrbuch der Liturgik 1951, $792 \mathrm{ev.}$

18) W. Balke, De avondmaals/eer van Zwingli, in: Bij Brood en Beker 1980, 152. 